
$\$$ Research Square
Preprints are preliminary reports that have not undergone peer review.
They should not be considered conclusive, used to inform clinical practice,
or referenced by the media as validated information.

\title{
Jackfruit trees as seed attractors and nurses of early recruitment of native plant species in a secondary forest in Brazil.
}

\section{Milena Gomes}

Universidade Estadual de Santa Cruz

\section{Eliana Cazetta}

Universidade Estadual de Santa Cruz

Ricardo Bovendorp

Universidade Estadual de Santa Cruz

Deborah Faria ( $\nabla$ deborahuesc@gmail.com )

Universidade Estadual de Santa Cruz https://orcid.org/0000-0002-0375-2887

\section{Research Article}

Keywords: Invasive alien species, native species, seed rain, recruitment, Atlantic Forest

Posted Date: June 23rd, 2021

DOl: https://doi.org/10.21203/rs.3.rs-188831/v1

License: (c) This work is licensed under a Creative Commons Attribution 4.0 International License.

Read Full License

Version of Record: A version of this preprint was published at Plant Ecology on August 7th, 2021. See the published version at https://doi.org/10.1007/s11258-021-01167-9. 


\section{Abstract}

The Atlantic Forest is one of the most threatened tropical forests in the world, being drastically reduced, fragmented and disturbed. The drastic process of anthropic occupation and exploitation of this biome has, in many cases, led to the introduction of exotic species, such as the jackfruits (Artocarpus heterophyllus). However, studies on the influence of jackfruits on the native biota are still scarce. Here we investigated the influence of fruit trees on the seed rain and early recruitment of seedlings in native remnants, comparing these patterns with those observed for a native species tapirira (Tapirira guianensis), which similarly to jackfruits, produces many fruits thruought the year, attracting a variety of frugivore species. Seed rain and seedlings observed under the jackfruits were both more abundant and equally rich to the assemblages reported under the native tapirira trees. In both species, co-specifics comprise a large part of the number of seeds (> 70\%) and seedlings (>45\%) individuals and, although they attract similar seed assemblages, seedling composition diverge, particularly when co-specifics are excluded. We reported that jackfruits can attract a diverse seed and seedling assemblages, and we find no evidence that the presence of jackfruits negatively affects the arrival and initial recruitment of native plant species in the study area. These results should be analysed with caution but considered when evaluating costs and benefits of management options to control exotic species.

\section{Introduction}

Exotic species, i.e. those occurring outside their natural geographic boundaries, are increasingly becoming a common feature in human-dominated landscapes (D'Antonio et al. 2001). Some of these aliens become invasive, aggressively establishing populations into native ecosystems, eventually becoming a threat to native biotas (Stohlgren et al. 1999). Indeed, biological invasions are among the leading causes of biodiversity loss (Simberloff et al. 2013; Wonham and Carlton 2005), a process occurring globally at unprecedented levels (Simberloff et al. 2013). Even those protected, relatively more pristine areas are now facing the consequences of biological invasions (Pauchard and Alaback 2004; Sala et al. 2000; Sampaio and Schmidt 2013), although the knowledge regarding its dynamics is still scarce (Usher et al. 1988). Understanding and predicting the impacts of invasive species depends on several factors, from the characteristics of the invasive species, the interaction with abiotic and biotic factors, and even anthropic influences on these dynamics (Dick et al. 2017; Ochocki and Miller 2017).

It has been assumed that invasive species can modify ecological interactions that have emerged throughout evolutionary times (Christian 2001; Traveset and Richardson 2014). Negative interactions between exotic and native plants are, therefore, expected as one of the most common and worrying consequences of biological invasions (Crooks 2002). However, a growing body of research also brings evidence that facilitating interactions between exotic and native species also occur, i.e. increases in densities and biomass of one or two interactive counterparts (Duffy and Baltz 1998; Schwindt et al. 2001). In some cases, the arrival of aliens can functionally replace native species lost or severely decreased by habitat disruptions (Rodriguez 2006), although critics claim for a more cautionary conclusion (Sotka and Byers 2019). 
In Brazil, a country most recognized to host a rich and unique biota, the introduction of jackfruits (Artocarpus heterophyllus, Moraceae) is among the best reported cases with greatest invasive potential and, therefore, often considered among the major threats to local biota (de Abreu and Rodrigues 2010). Native to Southeast Asia (Thomas 1980), the species was introduced in several countries for food, landscaping and, in the case of Brazil, was also used to restore a degraded area in the colonial capital of Rio de Janeiro (Abreu 2008). Jackfruits produce large, nutritious and abundant fleshy fruits highly appreciated by humans, but the species is also widely consumed by several frugivores from the local faunas, mainly mammals and birds (Lapenta and Procópio-de-Oliveira 2009; Mileri et al. 2012; Raíces et al. 2017). As a result of such massive consumption, large quantities of seeds may be dispersed (Faria et al. 2009; Oliveira et al. 2010), further expanding its distribution and increasing its potential to shape and structure plant and animal communities (Fabricante 2013). Although such situation often occurs in degraded areas, jackfruits are reported to be invading several protected areas in Brazil (Abreu 2008; Bergallo et al. 2016; Fabricante 2013; Raíces et al. 2017; Thomas 1980). Some studies alert that the presence of this species represents a significant threat to the phytodiversity of the Atlantic Forest (Abreu 2008; Barbosa 2016; Boni et al. 2009; Fabricante 2013; Mileri et al. 2012; Novelli et al. 2010), and managers are advised to take measures to control populations (Bergallo et al. 2020), including adult individuals' girdling, seedling withdrawal and chemical applications (Moura et al. 2020).

In the Atlantic Forest of southern Bahia, the largest remnants of coastal forests in the Northeastern Brazil, jackfruits are widespread elements in the regional forest mosaic, particulaly within the large area covered by cacao agroforestry, where this species is planted as fruiting and shading tree (Faria et al. 2009; Galindo-Leal and de Gusmao Camara 2003; Sambuichi et al. 2012). But it is also reported within native remnants, particularly those more degraded and secondary areas. For instance, a previous study has shown that a group of yellow-breasted-capuchins Sapajus xanthosternos, an endemic and threatened primate species inhabiting a protected area, consume and potentially disperse jackfruits (Canale et al. 2016). While foraging on such exotic species, which is more common on private properties surrounding the edge of Reserva Biológica de Una (Rebio-Una), these primates drop a rich and abundant seed rain comprising many native species consumed in mature and secondary forests (Bufalo et al. 2016; Cardoso et al. 2011; Oliveira et al. 2011). This primate species can potentially disperse jackfruit seeds within the forest reserve, with jackfruits also competing with native species for dispersal services (Canale et al. 2016). However, it is also important to understand whether seeds from native species drop under the jackfruits could potentially recruit or whether their development could be suppressed, for instance, by the high competition of jackfruit seedlings. Despite the potential of invading native areas, information regarding patterns of seed rain and seedling diversity and composition under the jackfruit crowns would feed the discussion on whether the ubiquitous presence of such exotics in disturbed areas could function as drain or sources for forest restoration (D'antonio and Meyerson 2002; Fridley et al. 2007).

In this context, we assessed patterns of seed rain and the early recruitment of seedlings under the canopy of jackfruits present in a secondary forest within the limits of a protected area in the south of Bahia, Brazil. We also undertook the same assessment for a native tree species known as tapirira (Tapirira guianensis), which is a pioneer species locally abundant in both primary and secondary forests, also 
consumed by a variety of frugivores (de Oliveira et al. 2017; Guimarães 2003; Oliveira et al. 2010). We predict that, once both species can attract a rich assemblage of native frugivores, seed rain will highly diverse (rich and abundant) under the canopy of both species, but the abundance and richness of seedlings from native species will be greater under the tapirira canopy because of the greater competitive pressure - possibly boosted by allelopathy - of jackfruit seedlings (Perdomo and Magalhaes 2007; Costalonga and Batitucci 2020).

\section{Materials And Methods}

\section{Study area}

The study was carried out in the Una Biological Reserve, here in Rebio-Una ( $15^{\circ} 17^{\prime} \mathrm{S}, 39^{\circ} 04^{\prime} \mathrm{W}$ ), located in the municipality of Una, Southern Bahia, Brazil (Fig. 1). It is a federally protected area representing one of the few and most important forest remnants of the Atlantic Forest of northeastern Bahia. The landscapes in the region are composed of forest fragments under different levels of regeneration, immersed in a complex matrix that includes pastures, secondary forest, and forest crops such as cocoa (Theobroma cacao), piaçava (Attalea funifera), and rubber trees (Hevea brasiliensis) (de Oliveira et al. 2017). The original vegetation is classified as wetland rainforest (Oliveira-Filho and Fontes 2000), a climatic type Af according to the classification of Köppen (Mori et al. 1983), characterized as wet and warm forests with annual precipitation of $1800 \mathrm{~mm}$, with no defined dry season and with average temperature at about $24-25^{\circ} \mathrm{C}$ (Mori et al. 1983).

\section{Sampling design}

We selected 14 individual trees of jackfruits and 14 of tapiriras located within the limits of a foraging area of a group of yellow-breasted-capuchins, monitored in a previous study conducted at RebioUna (Ferraço 2013). The area is partially located within the Rebio-Una, comprising a mosaic of mature and secondary forests, but also shade cacao and rubber tree plantations located on private properties bordering the limits of the reserve. We selected sampling trees in two areas, one with a predominance of tapiriras and without the presence of jackfruits in a radius of 200 meters, and another with a predominance of jackfruits and without tapiriras being absent within a radius of 200 meters (Fig. 1). In each area, a minimum distance of 10 meters between each sampling tree was observed.

\section{Seed rain and early recruitment}

A total of 56 seed traps were installed in the study area, 28 under the canopy of each focal species, 2 traps per plant. Each seed trap was fabricated with a $20 \mathrm{~mm}$ PVC tube, framing a $60 \mathrm{~cm} \times 60 \mathrm{~cm}$ net (synthetic - comprising a sampling area of $360 \mathrm{~cm}^{2}$ ), and was installed suspended approximately $50 \mathrm{~cm}$ from the ground. In each monitored tree we also installled one trap for seedling recruitment, basically consisting of a $60 \times 60 \mathrm{~cm}$ squared frame made by $20 \mathrm{~mm}$ PVC tube, located under each tree canopy within which all seedliongs were reported. The area under the canopy of each tree was divided into four quadrants and the traps were randomly placed near the trunk of the monitored tree, although we pre- 
defined that each quadrant would contain only one type of trap. Once in a month we counted and identified all seed and seedling individuals observed in each trap, accounting for all species and also excluding those co-specifics of each mother plant. After each counting, seeds were removed from traps, kept in paper bags, sent to the Laboratory of Applied Ecology at UESC where they were compared to a previous reference collection and identified at the lowest possible taxonomic level. By contrast, seed recruitment was considered by the set of seedlings recruited in each trap after the start of the study, including seedlings and juveniles, and each individual was tagged (plastic label attached by a cotton thread) to avoid counting twice. Seedlings were considered as 1. individuals up to $3 \mathrm{~mm}$ thick at the base of the plant; 2 . individuals with a single rod; 3 . seed recruitment was considered by the set of seedlings recruited in each trap after the start of the study, including seedlings and juveniles. Individuals with evidence of seed germination (follow the monthly follow-up for six months of the field). Seedlings were separated into morphospecies and identified at the family level whenever possible using the literature.We evaluated seed rain and recruitment plots each month for six months, except during July when sampling was not possible due to personal safety issues in the Rebio-Una.

\section{Statistical analyses}

We used Generalized Linear Models (GLM) to examine the differences in seedling and seed richness and abundance among $A$. heterophyllus and $T$. guianensis species. For this analysis, we assume as a categorical explanatory variable the combination of two factors, being the type factor (seeds and seedlings) and group factor (A. heterophyllus and T. guianensis). By combining these two factors we obtained an explanatory variable with four levels, we thus acquire a complete factorial that demonstrates the effect of abundance and seedling and seed richness among the focal species. Referring to the dispersion effect of seed abundance and seedling abundance, we used Poisson error distribution (loglinear models) and when the data presented over-dispersion, we assumed the quasiponisson approximation to correct the data.

To evaluate the taxonomic composition of seeds and seedlings between both focal species we performed a Permutational Multivariate Variance Analyzes (PERMANOVA) (Anderson and Walsh 2013) based on Bray-Curtis dissimilarity matrices. To understand the possible differences in seed and seedling composition among predictors, we used the non-metric Multidimensional Scaling (NMDS) analysis.

\section{Results}

After monitoring the 28 focal trees, we reported a total of 199 seeds from 30 species (Table 1) and 134 seedlings of 22 species. Under the jackfruits, we observed a total of 129 seeds, $80 \%$ comprising jackfruit seeds and the remaining seeds from 14 different species. Of the 70 seeds found under the Tapirira, $70 \%$ of the seeds were of 22 different species of tapirira (Table 1). In the same period, a total of 134 seedlings of 22 species were observed recruiting under the canopy of the two focal species. Of these, 79 seedlings from 11 species were observed under the jackfruit trees, 76\% comprising jackfruit seedlings, while under 
the tapirira we observed 55 seedlings from 6 species, with tapirira comprising $45 \%$ of these individuals (Table 2).

On average, seeds were more abundant than seedlings when all species are considered, but when cospecifics are discarded, i.e. after excluding seed and seedling from the mother plant, the average abundance of both seeds and seedling was significantly higher in jackfruits than those reported under the crown of the tapiriras (Fig. 2). However, we found no significant differences on average species richness of neither seeds nor seedlings between the two focal trees, even when co-specifics are excluded (Fig. 3).

We observed that each tree species comprised different assemblages of seeds under their crowns (Table 3 ), but only when co-specifics are included in the analysis, i.e. when seeds of jackfruits and tapirira are excluded from the assemblage reported bellow each mother plant, seeds composition did not differ between jackfruits and tapirira (Table 4). In this case, however, NMDS showed a larger variability on the composition among jackfruit individuals whereas this was more similar among those tapirira trees (Fig. 4). By contrast, each tree species comprised different assemblages of seedlings even after controlling for co-specifics. Nevertheless, the NMDS revealed that, when co-specifics are excluded, the similarity of seedling composition between both tree species increases (Fig. 4).

\section{Discussion}

Our study shows that jackfruits are important perches attracting an abundant and rich seed rain, largely comprising a variety of native species. On average, seed rain and seedling assemblages under the jackfruits were both more abundant and equally rich to the assemblages reported under the native tapirira trees. In both species, co-specifics comprise a large part of the number of seeds ( $>70 \%)$ and seedlings $(>45 \%)$ individuals. However, while both species attract similar assemblages of seeds, the composition of seedling assemblages diverge between focal species. Nevertheless, our analysis also showed that when co-specifics were excluded, the divergence between recruitment assemblage decreased.

The tropical climate along a large strip of the Atlantic Forest, with an intense frequency of rainfall and high average temperatures (Dean 1996), guarantees to the exotic species favorable conditions to abundant fruiting throughout the year. Each tree can produce more than 100 fruits, each averaging 500 seeds (de Abreu and Rodrigues 2010). Furthermore, the dispersal of the jackfruit seeds occurs mainly through barocory, therefore a major part of the fruits is deposited under the canopy of the mother plant (Abreu 2008; Bergallo et al. 2016; de Abreu and Rodrigues 2010; Morton 1965), often with a high recruitment rate (Fabricante 2013; Silva 2014b). In many cases, the high availability of fruits and seeds produced by this exotic species is so high that it exceeds the consumption capacity of frugivores, such as reported for an insular area in Brazil (Oliveira et al. 2010). This deficit of consumers is likely to be greater in defaunated areas because the low abundance of consumers further increases the abundance of viable seeds and recruiting individuals under the canopy of the jackfruits.

In addition to seed predation, terrestrial mammals may also play an important role in the secondary dispersal of jackfruits, consuming and dispersing the fallen seeds under the mother plant. Raíces et al. 
(2017) evaluating the role of mammals in the Jackfruit seed dispersal in Ilha Grande State Park, Brazil, found that the terrestrial mammalian species Didelphis aurita, Cuniculus paca, and Trinomys dimidiatus are among the main dispersers of jackfruit seeds. Plant species can compete for seed dispersers (Berghallo et al. 2016), particularly in highly defaunated areas. Therefore, the high local abundance of seeds of exotic species would increase its dispersal in detriment of this service to the remaining native species (Oliveira et al. 2010). In southern Bahia, primates represent one of the few frugivorous mammals capable of effectively disperse medium and large seeds, whose original dispersers are locally extinct due to hunting (Oliveira-Filho and Fontes 2000; Rocha et al. 2015). Oliveira et al. (2011), studying the use of agroforests in the same region where our study was concentrated reported that jackfruits are the only ubiquitous species registered in the diet of all groups of primates - the endemic golden-headed lion tamarins (Leontopithecus chrysomelas) - present in great abundance and being consumed during periods of fruit shortage. In this case, primates consume fruits still hanging on the tree, that is, before falling ripe to the ground. However, at least in the case of the primate $S$. xanthosthernos monitored at Rebio-Una, the dispersal effectiveness is quite small (de Oliveira et al. 2017). Even though the entire region of southern Bahia is highly defaunated (Canale et al. 2012), it is possible that the low density of extant medium-sized species, particularly inhabiting protected areas such as Rebio-Una, may help to disperse jackfruit seeds from the more urbanized areas surrounding this protected area to its interior (Cardoso et al. 2011; Mileri et al. 2012).

Although studies have shown that jackfruits can restrict the initial recruitment of native species, reducing the diversity of native plant assemblages (de Abreu and Rodrigues 2010; Fabricante 2013; Morton 1965; Novelli et al. 2010), we did not find any evidence for such effect in our study. The seed rain and recruiting assemblage reported under the monitored jackfruit individuals are both as diverse and as abundant when compared to the native tapirira, one of the most common pioneer species in secondary and primary forests (Oliveira et al. 2011; Silva and Tabarelli 2000). Besides, seed rain composition is similar between both focal species, even considering that jackfruits and tapirira differ regarding the foraging frugivore assemblage. The native species tapirira exhibits a high production of small black fruits, attracting a dispersing fauna different from that reported for the exotic species, like several birds with varied strategies of capture and manipulation of the seeds (Guimarães 2003; Ribeiro and Silva 2005; Silva 2014b). That is, while the primary and secondary dispersal of the jackfruits occurs, respectively, by barocory and terrestrial medium and large mammals (Alvino et al. 2005; Morton 1965; Oliveira et al. 2010; Thomas 1980), birds and small mammals are the main consumers and dispersers of tapirira fruits, even though primates also consume tapirira fruits. Despite these differences, when we excluded the presence of seeds produced by the mother plant, we found a high similarity in the composition of the seed rain between them. Both species present a rich, abundant and diverse seed rain, together comprising at least 21 species of native flora.

However, this similarity in the seed rain is not reflected in the composition of the recruiting assemblages. Indeed, among the major factors influencing plant recruitment are the availability - quantity and quality of suitable sites for germination and antagonistic interactions, such as local competition - particularly regarding co-specifics - and predation pressure (Alvino et al. 2005; Crawley 1990). These factors may act 
as barriers limiting seed recruitment at specific sites (Zimmerman et al. 2000). Differences in conditions under the canopy of the two species can determine different responses in the germination capacity, and survivor likelihood, of the seed assemblage. Among the emergent species highly abundant under the jackfruit canopies are some species characteristic of secondary succession. In particular, the genus Inga was very abundant and recruited exclusively under this exotic tree (Alvino et al. 2005). Inga and jackfruit seeds have similar characteristics, they are recalcitrant, have higher growth rates when exposed to light, and when water is reduced below $29 \%$, the seeds are unable to germinate (Barrozo et al. 2014; Silva 2014a). Although the jackfruit is classified as shade-tolerant species, its seeds germinate better in intermediate clearings than in shaded areas (Khan 2004). Nevertheless, it should be emphasized that the early recruitment of native plants under the jackfruits does not guarantee their establishment into the subsequent ontogenetic stages (Siqueira 2006). Most likely, as seedlings of this exotic species develop, these dynamics can change due to density-dependent mortality (Silva 2014a). In fact, Silva (2014a) evaluating the mortality of regenerant component of native species under jackfruit canopy revealed a lower abundance of native regenerants in the presence of the exotic species than in areas where the species was absent.

\section{Implications for conservation}

Habitat loss has led to a decrease in fruit availability in the southern region of Bahia, mainly from shadetolerant species (Pessoa et al. 2017). The presence of jackfruits within, or on properties in the vicinity of Rebio-Una might play an important role in the maintenance of frugivore populations in the region, mainly during periods of fruit shortage (Pessoa et al. 2017). Due to this characteristic, any recommendation or management strategy should require a deep and careful evaluation. Strategies to eradicate exotic plant species might also imply more complex and, sometimes, unattended effects such as those impacting local frugivores (Oliveira et al. 2011). Our results reinforce that this exotic species does attract a rich and abundant seed rain, comparable to those reported in other native and abundant plant species. More important, despite the high abundance of both seeds and recruits of jackfruits, which could decrease the likelihood of native recruits by competition or even allelopathy, we find no evidence that this exotic species limits the early recruitment of the native seedlings. Nevertheless, we don't know whether this pattern remains unchanged over time, i.e. it is possible to picture the jackfruits acting as an exotic element with relevance to forest regeneration and recovery of degraded areas. However, we highlight that (1) small differences in the composition of native seedlings recruited may represent large differences in the long term, and (2) the jackfruits may present a greater competitive advantage in later recruitment stages, limiting the recruitment of native species in more advanced ontogenetic phases and acting as an ecological filter with adverse effects under forest regeneration. To propose either the use or the control of jackfruits as options for management actions, it is essential to investigate in more detail whether recruits will successfully be established. Thus, it is necessary to move forward to better understand the role of these exotic trees in the successional trajectory of the local community.

\section{Declarations}




\section{Funding}

This study was possible due to research grants from Sisbiota/CNPq (grant number 563216/2010-70, PROPP/UESC (grant number 00220.1100.1774). DF and EC were granted by a CNPq fellowships (numbers 307990/2018-4 and 306373/2018-1, respectively) and MG was sponsored by a CNPq fellowship from Programa de Pós-Graduação em Ecologia e Conservação da Biodiversidade-PPGECB.

\section{Conflicts of interest/Competing interests}

Not applicable

\section{Ethics approval}

Not applicable

\section{Consent to participate}

All authors consented to participate in the manuscript

\section{Consent for publication}

All authors consent to publish the manuscritp under acceptance

\section{Availability of data and material}

The data that support the findings of this study will be available in the dryad repository

\section{Code availability}

Not applicable

\section{Authors' contributions}

Conceptualization: Deborah Faria and Milena Gomes; Methodology: Deborah Faria, Milena Gomes and Eliana Cazetta; Formal analysis and investigation: Milena Gomes; Writing - original draft preparation: Milena Gomes, Deborah Faria and Eliana Cazetta; Writing - Milena Gomes, Deborah Faria, Eliana Cazetta and Ricardo Bovendorp; Funding acquisition: Deborah Faria; Resources: Deborah Faria; Supervision: Deborah Faria

\section{References}

Abreu RCR (2008) Dinâmica de populações da espécie exótica invasora Artocarpus heterophyllus L. (Moraceae) no Parque Nacional da Tijuca-Rio de Janeiro. Master dissertation Instituto de Pesquisa Jardim 
Alvino FO, Silva MFF, Rayol BP (2005) Potencial de uso das espécies arbóreas de uma floresta secundária, na Zona Bragantina, Pará, Brasil. Acta Amazonica 35:413-420

Anderson MJ, Walsh DC (2013) PERMANOVA, ANOSIM, and the Mantel test in the face of heterogeneous dispersions: what null hypothesis are you testing? Ecological monographs 83:557-574

Barbosa U (2016) Aspectos ecológicos e influência de Artocarpus heterophyllus Lam. na estrutura do componente arbóreo de fragmento florestal urbano. Master dissertation, Universidade Federal Rural de Pernambuco

Barrozo LM, Ursulino EA, de Araujo LR, Sena DVA, de Medeiros DS, dos Santos JC (2014) Quality seeds Inga physiological function of drying. Biosci J 30:645-654

Bergallo HG, Bergallo AC, Rocha HB, Rocha CFD (2016) Invasion by Artocarpus heterophyllus (Moraceae) in an island in the Atlantic Forest Biome, Brazil: distribution at the landscape level, density and need for control. Journal of Coastal Conservation 20:191-198Boni R, Novelli FZ, Silva AG (2009) Um alerta para os riscos de bioinvasão de jaqueiras, Artocarpus heterophyllus Lam., na Reserva Biológica Paulo Fraga Rodrigues, antiga Reserva Biológica Duas Bocas, no Espírito Santo, Sudeste do Brasil. CEP 29140:500

Bufalo FS, Galetti M, Culot L (2016) Seed dispersal by primates and implications for the conservation of a biodiversity hotspot, the Atlantic forest of South America. International Journal of Primatology 37:333349

Canale GR, Peres CA, Guidorizzi CE, Gatto CA, Kierulff MC (2012) Pervasive defaunation of forest remnants in a tropical biodiversity hotspot. Plos One 7:e41671. doi:10.1371/journal.pone.0041671

Canale GR, Suscke P, Rocha-Santos L, Bernardo CS, Martins Kierulff MC, Chivers DJ (2016) Seed dispersal of threatened tree species by a critically endangered primate in a Brazilian Hotspot. Folia Primatol (Basel) 87:123-140. doi:10.1159/000447712

Cardoso NA, Le Pendu Y, Lapenta MJ, Raboy BE (2011) Frugivory patterns and seed dispersal by goldenheaded lion tamarins (Leontopithecus chrysomelas) in Una Biological Reserve, Bahia, Brazil. Mammalia 75:327-337. doi:10.1515/mamm.2011.042

Christian CE (2001) Consequences of abiological invasion reveal the importance of mutualism for plant communities. Nature 413:635-639

Costalonga SA, Batitucci MdCP (2020) Avaliação alelopática e fitoquímica de Artocarpus heterophyllus Lam. e Eriobotrya japonica (Thunb.) Lindl., duas espécies invasoras presentes em unidades de conservação do Espírito Santo, Brasil. Brazilian Journal of Development 6:56486-56505

Crawley MJ (1990) The population dynamics of plants. Philosophical Transactions of the Royal Society of London Series B: Biological Sciences 330:125-140 
Crooks JA (2002) Characterizing ecosystem-level consequences of biological invasions: the role of ecosystem engineers. Oikos 97:153-166

D'antonio C, Meyerson LA (2002) Exotic plant species as problems and solutions in ecological restoration: a synthesis. Restoration Ecology 10:703-713

D'Antonio C, Meyerson LA, Denslow JS (2001) Exotic species and conservation: research needs. In: Soulé $\mathrm{ME}$, Orians GH (eds) Conservation Biology. Research priorities for the next decade. Island Press, Washington, pp 59-80

de Abreu RC, Rodrigues PJF (2010) Exotic tree Artocarpus heterophyllus (Moraceae) invades the Brazilian Atlantic Rainforest / Árvore exótica Artocarpus heterophyllus (Moraceae) invade a Mata Atlântica brasileira. Rodriguésia-Instituto de Pesquisas Jardim Botânico do Rio de Janeiro 61

de Oliveira SN, de Carvalho Júnior OA, Gomes RAT, Guimaraes RF, McManus CM (2017) Landscapefragmentation change due to recent agricultural expansion in the Brazilian Savanna, Western Bahia, Brazil. Regional environmental change 17:411-423

Dean W (1996) A ferro e fogo: a história e a devastação da Mata Atlântica brasileira. Companhia das Letras, São Paulo

Dick JT et al. (2017) Invader Relative Impact Potential: a new metric to understand and predict the ecological impacts of existing, emerging and future invasive alien species. Journal of Applied Ecology 54:1259-1267

Duffy KC, Baltz DM (1998) Comparison of fish assemblages associated with native and exotic submerged macrophytes in the Lake Pontchartrain estuary, USA. J Exp Mar Biol Ecol 223:199-221

Fabricante JR (2013) Sociabilidade de espécies da mata atlântica com a exótica invasora Artocarpus heterophyllus Lam. Revista De Biologia Neotropical/Journal of Neotropical Biology 10:18-25

Faria D et al. (2009) Forest structure in a mosaic of rainforest sites: the effect of fragmentation and recovery after clear cut. Forest Ecology and Management 257:2226-2234

Ferraço LL (2013) Efetividade da dispersão de sementes pelo macaco-prego-do-peito-amarelo (Sapajus xanthosternos, Primates: Cebidae) em um mosaico florestal da Mata Atlântica: implicações para a regeneração de florestas., Master Dissertation, Universidade Estadual de Santa Cruz

Fridley JD et al. (2007) The invasion paradox: Reconciling pattern and process in species invasions. Ecology 88:3-17. doi:10.1890/0012-9658(2007)88[3:tiprpa]2.0.co;2

Galindo-Leal C, de Gusmao Camara I (2003) The Atlantic forest of South America: Biodiversity status, threats, and outlook. Center for Applied Biodiversity Science and Island Press, 
Guimarães MA (2003) Frugivoria por aves em Tapirira guianensis (Anacardiaceae) na zona urbana do município de Araruama, estado do Rio de Janeiro, sudeste brasileiro. Atualidades ornitológicas 116:12

Khan ML (2004) Effects of seed mass on seedling success in Artocarpus heterophyllus Lam., a tropical tree species of north-east India. Acta Oecologica:103-110

Lapenta MJ, Procópio-de-Oliveira P (2009) The Fate of Seeds Dispersed by Golden Lion Tamarins (Leontopithecus rosalia) in an Atlantic Forest Fragment, Brazil. Tropical Conservation Science 2:266-281

Mileri M, Passamani M, Eutrópio F, Oliveira A (2012) Removal of seeds of exotic jackfruit trees (Artocarpus heterophyllus, Moraceae) in native forest areas with predominance of jackfruit trees in the Duas Bocas Biological Reserve, Southeastern Brazil. International Journal of Ecosystem 2:93-98

Mori SA, Boom BM, Carvalho AM, Santos TS (1983) Southern Bahian moist forests. The Botanical Review 49:155-232

Morton JF (1965) The Jackfruit (Artocarpus heterophyllus Lam.):* Its Culture, Varieties and Utilization. Proceedings of the Florida State Horticultural Society 78:336-344

Moura CJR, Gaspar M, Bergallo HG, Lacerda AC, Ferreguetti A (2020). Closing the Snack Bar: Developing Methods for Jackfruit Tree (Artocarpus heterophyllus Lamk.) Control in Brazil. FLORAM 27:1-10.Novelli FZ, Moreira RPG, Duca C, Silva AG (2010) O papel da barocoria na estruturação da população da jaqueira, Artocarpus heterophyllus Lam. na Reserva Biológica de Duas Bocas, Cariacica, Espírito Santo. Natureza on line 8:91-94

Ochocki BM, Miller TE (2017) Rapid evolution of dispersal ability makes biological invasions faster and more variable. Nat Commun 8:14315. doi:10.1038/ncomms14315

Oliveira L, Hankerson S, Dietz J, Raboy B (2010) Key tree species for the golden-headed lion tamarin and implications for shade-cocoa management in southern Bahia, Brazil. Animal Conservation 13:60-70

Oliveira LC, Neves LG, Raboy BE, Dietz JM (2011) Abundance of jackfruit (Artocarpus heterophyllus) affects group characteristics and use of space by golden-headed lion tamarins (Leontopithecus chrysomelas) in Cabruca agroforest. Environ Manage 48:248-262. doi:10.1007/s00267-010-9582-3

Oliveira-Filho AT, Fontes MAL (2000) Patterns of floristic differentiation among Atlantic forests in southeastern Brazil and the influence of climate. Biotropica 32:793 - 810

Pauchard A, Alaback PB (2004) Influence of elevation, land use, and landscape context on patterns of alien plant invasions along roadsides in protected areas of South-Central Chile. Conservation Biology 18:238-248

Perdomo M, Magalhães LMS (2007). Ação alelopática da jaqueira (Artocarpus heterophyllus) em laboratório. Floresta Ambiente 14: 52-55. 
Pessoa MS, Rocha-Santos L, Talora DC, Faria D, Mariano-Neto E, Hambuckers A, Cazetta E (2017) Fruit biomass availability along a forest cover gradient. Biotropica 49:45-55

Raíces DS, Ferreira PM, Mello JH, Bergallo HG (2017) Smile, you are on camera or in a live trap! The role of mammals in dispersion of jackfruit and native seeds in Ilha Grande State Park, Brazil. Nature Conservation Research 2:78-89

Ribeiro LB, Silva MG (2005) Comportamento alimentar das aves Pitangus sulphuratus, Coereba flaveola e Thraupis sayaca em palmeiras frutificadas em área urbana. Revista de Etologia 7:39-42

Rocha JS, Bomfim FCG, Bernardo CSS (2015) Importância da reserva biológica de una na conservação de mamíferos da Mata Atlântica do Sul da Bahia vol 1. XII Congresso de Ecologia do Brasil, São Lourenço, MG, Brasil

Rodriguez LF (2006) Can invasive species facilitate native species? Evidence of how, when, and why these impacts occur. Biological Invasions 8:927-939

Sala OE et al. (2000) Global biodiversity scenarios for the year 2100. Science 287:1770-1774. doi:10.1126/science.287.5459.1770

Sambuichi RHR et al. (2012) Cabruca agroforests in southern Bahia, Brazil: tree component, management practices and tree species conservation. Biodiversity and Conservation 21:1055-1077. doi:10.1007/s10531-012-0240-3

Sampaio AB, Schmidt IB (2013) Espécies exóticas invasoras em unidades de conservação federais do Brasil. Biodiversidade Brasileira-BioBrasil:32-49

Schwindt E, Bortolus A, Iribarne $O O$ (2001) Invasion of a reef-builder polychaete: direct and indirect impacts on the native benthic community structure. Biological Invasions 3:137-149

Silva AMd (2014a) Avaliação da Regeneração de espécies nativas e da influência de Artocarpus heterophyllus L. na fitodiversidade de uma área de Floresta Atlântica. Master Dissertation, Universidade Federal Rural de Pernambuco

Silva C (2014b) Primeiro registro do sabiá-una Turdus flavipes (Passeriformes: Turdidae) para o estado de Sergipe, nordeste do Brasil. Atualidades Ornitólogicas 177:18-19

Silva JMC, Tabarelli M (2000) Tree species impoverishment and the future flora of the Atlantic forest of northeast Brazil. Nature 404:72-74

Simberloff D et al. (2013) Impacts of biological invasions: what's what and the way forward. Trends Ecol Evol 28:58-66. doi:10.1016/j.tree.2012.07.013 
Siqueira JD (2006) Bioinvasão vegetal: dispersão e propagação de espécies nativas e invasoras exóticas no campus da Pontifícia Universidade Católica do Rio de Janeiro (PUC-Rio). Pesquisas Botânica 57:319330

Sotka E, Byers J (2019) Not so fast: promoting invasive species to enhance multifunctionality in a native ecosystem requires strong (er) scrutiny. Biological Invasions 21:19-25

Stohlgren TJ et al. (1999) Exotic plant species invade hot spots of native plant diversity. Ecological monographs 69:25-46

Thomas C (1980) Jackfruit, Artocarpus heterophyllus (Moraceae), as source of food and income. Economic Botany 34:154-159

Traveset A, Richardson DM (2014) Mutualistic interactions and biological invasions. Annual Review of Ecology, Evolution, and Systematics 45:89-113

Usher M, Kruger F, Macdonald I, Loope L, Brockie R (1988) The ecology of biological invasions into nature reserves: an introduction. Biological Conservation 44:1-8

Wonham MJ, Carlton JT (2005) Trends in marine biological invasions at local and regional scales: the Northeast Pacific Ocean as a model system. Biological invasions 7:369-392

Zimmerman JK, Pascarella JB, Aide TM (2000) Barriers to forest regeneration in an abandoned pasture in Puerto Rico. Restoration ecology 8:350-360

\section{Tables}

Table 1 Composition of seed species deposited under the canopy of the jackfruits (Artocarpus heterophyllus) and tapirira (Tapirira guianensis) in the Una Biological Reserve, Bahia, Brazil. 


\begin{tabular}{|c|c|c|c|c|}
\hline Family & Species & $\begin{array}{l}\text { Total } \\
\text { collected }\end{array}$ & $\begin{array}{l}\text { jackfruit } \\
\text { trees }\end{array}$ & $\begin{array}{l}\text { tapirira } \\
\text { trees }\end{array}$ \\
\hline Anacardiaceae & Tapirira guianensis & 22 & 0 & 22 \\
\hline Arecaceae & Elaeis guianensis & 6 & 1 & 5 \\
\hline Arecaceae & Euterpe edulis & 1 & 1 & 0 \\
\hline Cannabaceae & Celtis ehrenbergiana & 4 & 1 & 3 \\
\hline Erythroxylaceae & sp. I & 2 & 0 & 2 \\
\hline Euphorbiaceae & Brasiliocroton mamoninha & 3 & 0 & 3 \\
\hline Euphorbiaceae & sp. I & 1 & 0 & 1 \\
\hline Euphorbiaceae & Manihot glaziovii & 2 & 1 & 1 \\
\hline \multirow[t]{2}{*}{ Fabaceae } & Andira surinamensis & 2 & 0 & 2 \\
\hline & Sparattanthelium & & & \\
\hline Hernandiaceae & botocudorum & 2 & 0 & 2 \\
\hline Malvaceae & Ceiba ventricosa & 3 & 2 & 1 \\
\hline Malvaceae & Eriotheca globosa & 2 & 1 & 1 \\
\hline Malvaceae & Theobroma cacao & 5 & 4 & 1 \\
\hline Meliaceae & Trichilia casaretti & 1 & 0 & 1 \\
\hline Moraceae & Artocarpus heterophyllus & 104 & 104 & 0 \\
\hline Moraceae & Brosimum glaziovii & 2 & 2 & 0 \\
\hline Moraceae & Brosimum rubescens & 1 & 0 & 1 \\
\hline Moraceae & Ficus clusiifolia & 2 & 0 & 2 \\
\hline Moraceae & Ficus gomelleira & 2 & 0 & 2 \\
\hline Peraceae & Chaetocarpus echinocarpus & 3 & 1 & 2 \\
\hline Polygonaceae & Coccoloba rósea & 3 & 0 & 3 \\
\hline Rubiaceae & sp. I & 2 & 2 & 0 \\
\hline Sapindaceae & Cupania scrobiculata & 1 & 1 & 0 \\
\hline \multirow[t]{3}{*}{ Sapindaceae } & Matayba guianensis & 2 & 0 & 2 \\
\hline & Morfospecies I & 1 & 1 & 0 \\
\hline & Morfospecies II & 1 & 1 & 0 \\
\hline
\end{tabular}




\begin{tabular}{lllll} 
Morfospecies III & 6 & 1 & 5 \\
\hline Morfospecies IV & 2 & 0 & 2 \\
\hline Morfospecies V & 5 & 1 & 4 \\
\hline Morfospecies VI & 4 & 3 & 1 \\
\hline Morfospecies VII & 1 & 0 & 1 \\
\hline Morfospecies VIII & 1 & 1 & 0 \\
\hline
\end{tabular}

Table 2 Composition of seedlings recruited under the canopy of the jackfruits (Artocarpus he 


\begin{tabular}{|c|c|c|c|c|}
\hline Family & Species & Total collected & jackfruit trees & tapirira trees \\
\hline Anacardiaceae & Tapirira guianensis & 25 & 0 & 25 \\
\hline \multirow[t]{2}{*}{ Apocynaceae } & sp. I & 2 & 0 & 2 \\
\hline & sp. II & 1 & 0 & 1 \\
\hline Burseraceae & Protium heptaphyllum & 5 & 0 & 5 \\
\hline Clusiaceae & sp. I & 2 & 0 & 2 \\
\hline \multirow[t]{2}{*}{ Euphorbiaceae } & Mabea sp. & 1 & 0 & 1 \\
\hline & Sorocea sp. & 5 & 2 & 3 \\
\hline Fabaceae & Inga sp. & 6 & 6 & 0 \\
\hline \multirow[t]{2}{*}{ Moraceae } & sp. I & 1 & 1 & 0 \\
\hline & Artocarpus heterophyllus & 60 & 60 & 0 \\
\hline Myrtaceae & sp. I & 2 & 2 & 0 \\
\hline \multirow[t]{3}{*}{ Rubiaceae } & sp. I & 4 & 0 & 4 \\
\hline & sp. II & 3 & 0 & 3 \\
\hline & sp. III & 1 & 0 & 1 \\
\hline Sapindaceae & sp. I & 2 & 1 & 1 \\
\hline Sapotaceae & sp. I & 1 & 1 & 0 \\
\hline \multirow[t]{6}{*}{ Vochysiaceae } & sp. I & 2 & 0 & 2 \\
\hline & Morfospecies I & 1 & 1 & 0 \\
\hline & Morfospecies II & 2 & 1 & 1 \\
\hline & Morfospecies III & 2 & 1 & 1 \\
\hline & Morfospecies IV & 4 & 2 & 2 \\
\hline & Morfospecies V & 2 & 1 & 1 \\
\hline
\end{tabular}

Table 3 Generalized linear model constructed with abundance and richness for assemblanges for all species and excluding co-specifics with coeficients of tree species, seed and seedlings and tree species and seed and seedlings of the Artocarpus heterophyllus and Tapirira guianensis in the Una Biological Reserve, Bahia, Brazil. 


\begin{tabular}{|c|c|c|c|c|c|c|}
\hline Metric & Assemblages & Coefficients & Estimate & Std.Error & t.value & $\mathrm{p}$ \\
\hline \multirow[t]{6}{*}{ Abundance } & All species ${ }^{2}$ & Tree species & -0.2834 & 0.2748 & -1.0310 & 0.30 \\
\hline & & Seeds and seedlings & 0.4845 & 0.2289 & 2.116 & $0.03 *$ \\
\hline & & $\begin{array}{l}\text { Tree species and Seeds } \\
\text { and seedlings }\end{array}$ & -0.2409 & 0.3595 & -0.670 & 0.50 \\
\hline & $\begin{array}{l}\text { Excluding co- } \\
\text { specifics }^{1}\end{array}$ & Tree species & 0.6061 & 0.2930 & 2.069 & $0.03 *$ \\
\hline & & Seeds and seedlings & 0.1054 & 0.3249 & 0.324 & 0.74 \\
\hline & & $\begin{array}{l}\text { Tree species and Seeds } \\
\text { and seedlings }\end{array}$ & 0.3684 & 0.3934 & 0.937 & 0.34 \\
\hline \multirow[t]{6}{*}{ Richness } & All species ${ }^{1}$ & Tree species & 0.3409 & 0.2312 & 1.474 & 0.14 \\
\hline & & Seeds and seedlings & 0.0307 & 0.2481 & 0.124 & 0.90 \\
\hline & & $\begin{array}{l}\text { Tree species and Seeds } \\
\text { and seedlings }\end{array}$ & -0.0532 & 0.3263 & -0.163 & 0.87 \\
\hline & $\begin{array}{l}\text { Excluding co- } \\
\text { specifics }^{1}\end{array}$ & Tree species & 0.5436 & 0.2963 & 1.834 & 0.06 \\
\hline & & Seeds and seedlings & 0.0540 & 0.3289 & 0.164 & 0.86 \\
\hline & & $\begin{array}{l}\text { Tree species and Seeds } \\
\text { and seedlings }\end{array}$ & 0.1495 & 0.4083 & 0.366 & 0.71 \\
\hline
\end{tabular}

Significant $p$ values $(p<0.05)$ are assigned by*. Abundance or richness models followed the Poisson ${ }^{1}$ or Quasi Poisson ${ }^{2}$ distributions

Table 4 Results of the PERMANOVA based on the Bray-Curtis similarity matrix for seeds and seedlings. 


\begin{tabular}{lcc}
\hline Source of variation & $F$ & $P$ \\
\hline Total seeds & 12,49 & $0,0001^{*}$ \\
Seeds without mother plant effect & 1,651 & 0,0746 \\
Total seedlings & 15,44 & $0,0001^{*}$ \\
Seedlings without mother plant effect & 2,721 & $0,0025^{*}$ \\
\hline
\end{tabular}

Significant $p$ values $(p<0.05)$ are assigned by*.

\section{Figures}

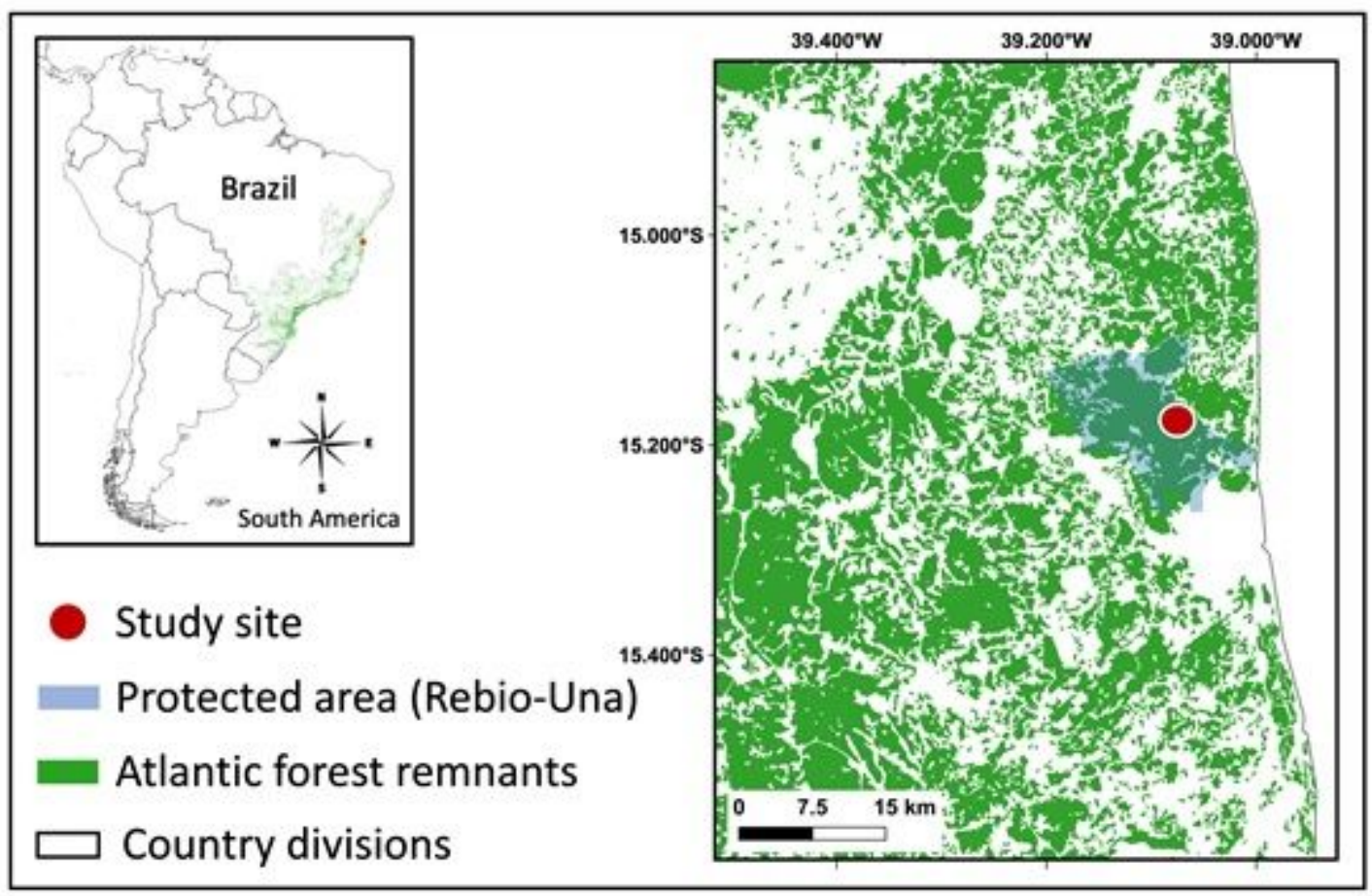

Figure 1

Study site at the Una Biological Reserve (Rebio-Una) southern Bahia, Brazil. 


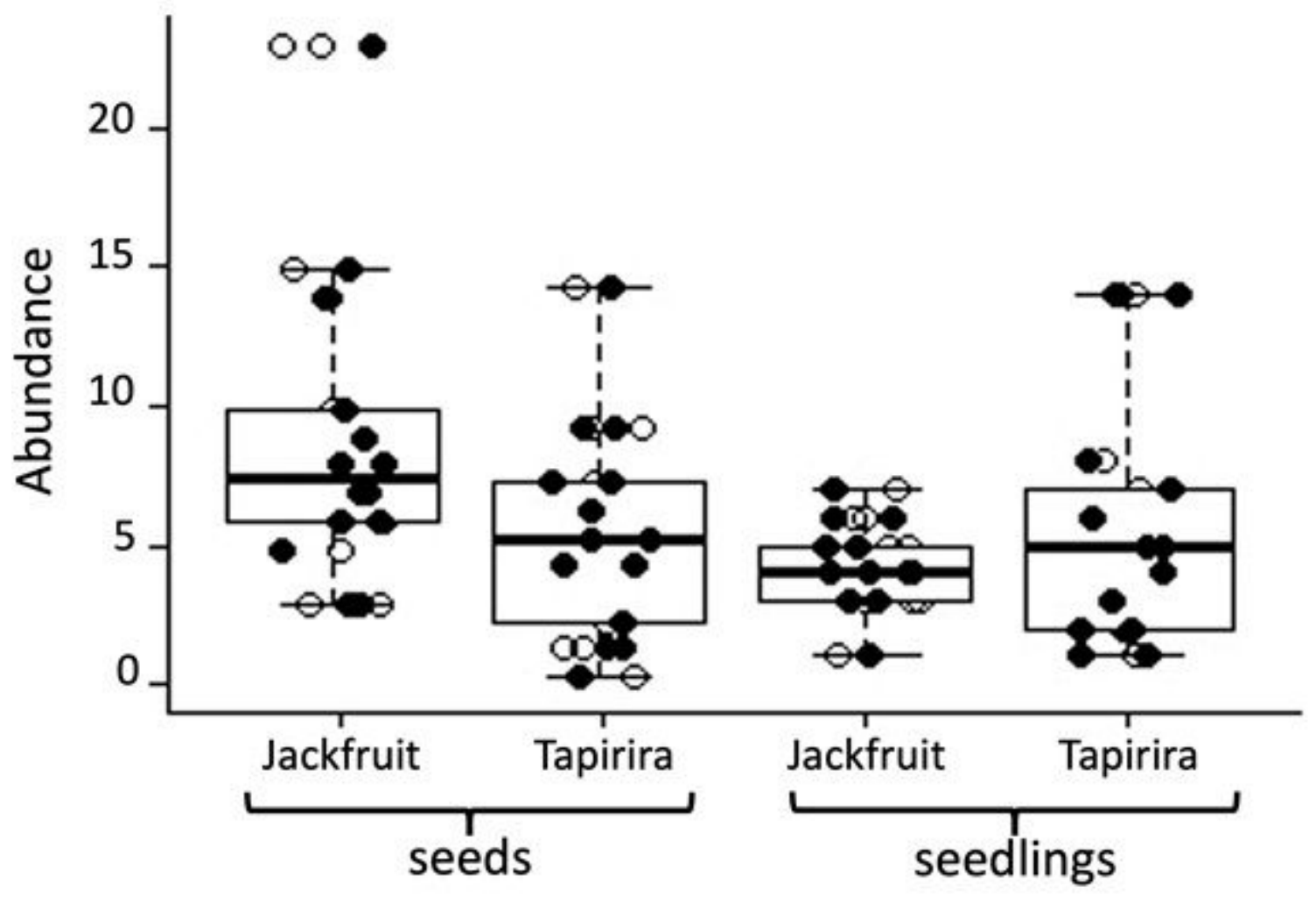

Figure 2

Abundance of seeds and seedlings reported under the crown of jackfruits (Artocarpus heterophyllus) and tapirira (Tapirira guianensis) in southern Bahia, Brazil.

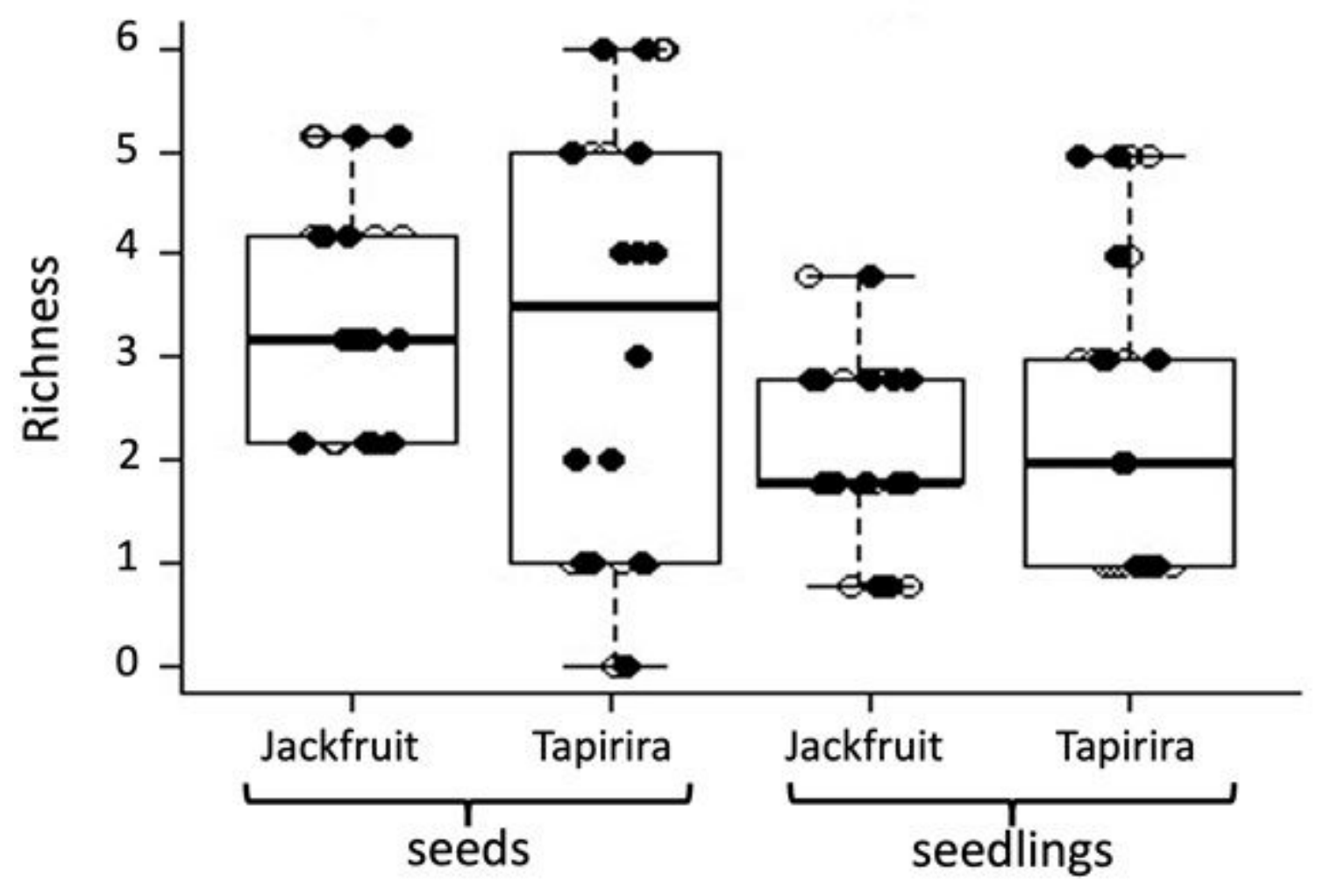

Figure 3 
Mean species richness of seeds $(a, b)$ and seedlings $(c, d)$ reported under the crown of jackfruits (Artocarpus heterophyllus) and tapirira (Tapirira guianensis) in southern Bahia, Brazil.
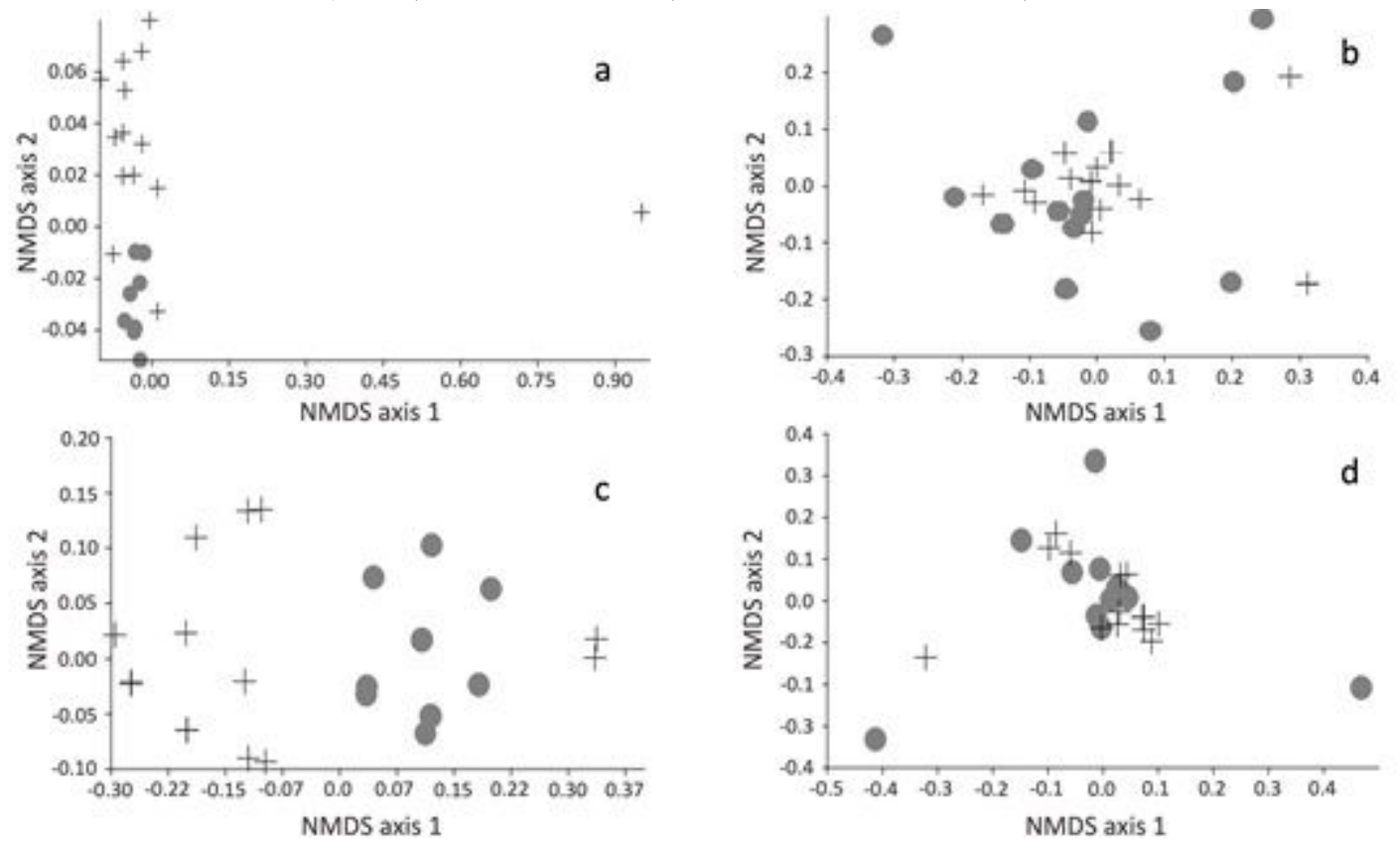

\section{Figure 4}

Multidimensional Non-Metric Scaling (NMDS) of the composition of seeds $(a, b)$ and seedling $(c, d)$ assemblages, considering all seedlings assemblages $(a, c)$ and when co-specifics (seeds from mother plant) are not considered (b, d) present under the canopy of the jackfruit (Artocarpus heterophyllus) and tapirira (Tapirira guianensis) trees, in southern Bahia, Brazil. Full circles $(\cdot)$ and add signs $(+)$ depict the set of seedlings recruited under jackfruits and tapirira trees, respectively. 